\title{
Tarımsal Arazi Değerlemesinde Mevcut Sorunlar ve Çözüm Yaklaşımları
}

\author{
Volkan BAŞER ${ }^{1^{*}}$
}

\begin{abstract}
Öz
Türkiye'nin topraklarının büyük bir çoğunluğu yapısız alanlardan oluşmakta, tarım arazi varlığı ise yaklaşık \%30 olarak dikkat çekmektedir. Bunun dı̧̧ında kentsel alanda olup tarımsal faaliyette kullanılan taşınmazlarda tarım arazi özellikleri ile değerlendirilmektedir. Bu çalışmada tarım arazilerinin değerlemesinde yaşanan sorunların tespit edilmesi ve çözüm yaklaşımlarının geliştirilmesi amaçlanmıştır. Alanda uzman ve akademisyenler ile yarı yapılandırılmış mülakat formu geliştirilmiştir. Soruların kapsam geçerliliğ̣i ve anlaşılabilirliği sağlandıktan sonra mülakatlar alanda uzman farklı disiplinlerden 12 kişi ile yüz yüze gerçekleştirilmiştir. Mahkemelere sunulmuş bilirkişi raporları sağlanmış ve incelenmiştir. Çalışmadan elde edilen en önemli sonuçlar şu şekilde özetlenebilir: Meslekler arası çatışma, taşınmazın ve davanın özelliğine göre farklı disiplinleri de içerecek şekilde bilirkişi belirlenememesi, basmakalıp ve yetersiz bilirkişi raporları hazırlanması, raporların yargı denetimi dışında bir denetime tabi olmaması, tekâmül etmemiş dosyalarla keşif icra edilmesi, dosyaların bilirkişilerce tekâmülünün sağlanması, emsal taşınmaz tespitinin yeterli nitelikte yapılamaması, emsal taşınmaz tespiti devamında değerleme kriterleri ve ağırlıklarının sübjektif olarak belirlenmesi, yargı denetiminden geçmiş emsal taşınmazlarla ilgili bir veri tabanı olmayışı sıralanabilir. Çözüm olarak ise tüm bu sorunları bertaraf edecek karar destek sistemlerinin e-Türkiye üzerinden tesis edilmesi söylenebilir.
\end{abstract}

Anahtar Kelimeler: Değerleme, Taşınmaz, Tarım Arazisi. Arazi Yönetimi.

\section{The Problems and Resolution Approaches in Agricultural Land Valuation}

\begin{abstract}
The vast majority of the country's land consists of unstructured areas, while the presence of agricultural land attracts attention to approximately $30 \%$. In addition, agricultural properties are used in real estate properties used in agricultural activities in urban areas. In this study, it is aimed to identify the problems experienced in the valuation of agricultural land and to develop solution approaches. Semi-structured interview form was developed with experts and academicians in the field. After ensuring the validity and comprehensibility of the questions, the interviews were conducted face to face with 12 people from different disciplines who are experts in the field. Expert reports submitted to the courts were provided and examined. The most important results of the study can be summarized as follows. Conflict between professions, failure to identify experts to include different disciplines according to the nature of real estate and the case, preparation of stereotypical and inadequate expert reports, reports not subject to an audit other than judicial review, execution of discovery with un-developed files, adequate determination of files by competent experts. In addition, the valuation criteria and their weights are subjectively determined, the lack of a database on the peer-reviewed real estates. As a solution for all these problems is through e-Turkey said that the establishment of decision support systems will be eliminated.
\end{abstract}

Keywords: Valuation, Real Estate, Agricultural Land, Land Management.

${ }^{1}$ Giresun Üniversitesi, Mühendislik Fakültesi, Harita Mühendisliği Bölümü, Giresun, Türkiye, volkan.baser@giresun.edu.tr

${ }^{1}$ https://orcid.org/0000-0001-5353-2287 


\section{Giriş}

Arazi yönetimi, arazi kaynaklarını etkin kullanabilme işlemidir. Arazi yönetiminin, arazinin sahipliği, arazi değeri, arazi kullanımı ve arazi gelişimi olmak üzere birbirleriyle ilişkili dört fonksiyonu bulunmaktadır (Enemark, 2012). Bu bağlamda birçok etkeni içinde barındıran karmaşık bir yapıya sahip olan taşınmaz, hem dünya ekonomisinde hem de ülkemizde önemli bir yatırım aracıdır (Yalçın, Selçuk, \& Şentürk, 2018). Taşınmaz değerlenme işlemi de bu kapsamlı yapının bir ayağıdır. Bu nedenledir ki taşınmazın değerinin belirlenmesi objektif kriterlerle yapılmalıdır (Başer, Biyik, Uzun, Yildirim, \& Nişanc1, 2016). Arazi değerini toprak kalitesi, parsellerin konumu, pazarlara olan mesafenin yanı sıra en yakın şehre olan uzaklık arazi değerlerini etkilediği görülmüştür (Choumert \& Phélinas, 2015).

Taşınmaz malların değer takdiri çeşitli kurumlarca farklı isimler altında yapılmaktadır. Bunlar; gayrimenkul değerleme, değer takdiri ve değerleme, kıymet takdiri ve değer belirleme vb. şeklindedir. Taşınmaz değerlemesi Sermaye Piyasası Kurulu (SPK) öncülüğünde Türkiye Değerleme Uzmanları Birliğinin kurulması ve SPK lisanslı değerleme uzmanlarının faaliyet göstermesi ile yeni bir uzmanlık alanı doğurmuştur. Özellikle kamulaştırma davalarının, farklı nitelikte birçok taşınmaz içermesi, değerleme işleminin önemini daha da arttırmaktadır. Tüm bu yapı içinde değerleme konusunu yöneten bir kamu otoritesi boşluğu tartışılırken (Özalp, Akıncı, \& Kılıçer, 2020), Tapu ve Kadastro Genel Müdürlüğüne bağlı Taşınmaz Değerleme Daire Başkanlığı, Cumhurbaşkanlığı Kararnamesi (Gazete, 2018) ile kurulmuştur. Değerleme konusunun önemli olması ve çok farklı disiplini bir araya getirmesi ister istemez farklı tartışmalara da sebebiyet verebilmektedir. Arsa, arazi ve bina nitelikli taşınmazların değerlemesinde harita mühendisleri, ziraat mühendisleri ve inşaat mühendisleri ön plana çıkmaktadır. İşin içine imar planı, orman, jeolojik sakıncalı alanlar, denizel alanlar gibi farklı nitelikler girdiğinde farklı uzmanlık alanları da konuya dâhil olabilmektedir.

Tarımsal arazilerin değerlendirilmesi taşınmaz değerlemenin önemli bir bölümünü oluşturmaktadır. Tarım arazilerinin değerlemesi yapılırken taşınmaz değerleme hususlarında dikkat edilen faktörler aynı şekilde dikkate alınır. Bir taşınmazın vasfı (arsa veya arazi) o taşınmazın değerlemesi yapılırken dikkat edilecek kriterlerin farklılaşmasına sebebiyet verebilmektedir.

Türkiye'de tarım arazileri, 2002 yılında 26 milyon 579 bin hektar iken 2019'de 23 milyon 94 bin hektara kadar düşerek 18 senede yüzde 12,3 oranında azalmıştır (TUIK, 2020). Yüzölçümü 780 bin $\mathrm{km}^{2}$ olan Türkiye'nin \%30’u tarım arazisi niteliğindedir. Son yıllardaki azalmalara rağmen bu oran oldukça yüksektir ve değerleme işlemini önemli kılmaktadır. Tarım arazilerinin bazıları hâlihazırda arsa olarak da kullanılabilmektedir. $\mathrm{Bu}$ tip arazilerin değerlemesi arsa nitelikli taşınmazların değerlemesi şeklinde yapılmaktadır. Eğer üzerinde zirai ürünler veya muhdesat mevcut ise bunlar zemin değeri üzerine eklenerek taşınmazın değeri hesaplanmaktadır. Tersi durumda ise, 
yani taşınmaz arsa olarak kullanılıyor ancak arazi vasfında ise, bu tip taşınmazlar da arsa olarak değerlendirilmektedir. Belediye ya da mücavir alan sınırları içinde olup, belediye ve diğer kamu kuruluşlarınca getirilmiş yol, su, elektrik, ulaşım, çöp toplama, kanalizasyon, aydınlatma gibi belediye ve altyapı hizmetlerinden yararlanan yerler arasında bulunmayan taşınmazlar da arazi niteliği ile değerlemeye konu edilirler (Yargıtay 18. Hukuk Dairesi 2014/4328 E., 2014/6755 K.). Ayrıca emlak vergisi noktasında, belediye veya mücavir alan sınırları içindeki taşınmazların hangi vasıf ile vergiye konu edileceği de farklı uygulamalara sebebiyet verebilmektedir.

Yapılan bu çalışmada esas amaç taşınmaz değerlemesine konu tarım arazilerinin değerlendirilmesinde hangi hususlara dikkat edilmesi gerektiği ve diğer taşınmazların değerlemesinde kullanılan yöntemlerden nerelerde ayrıldığını, değerlemede oluşan mevcut sorunlara nasıl çözümlerle yaklaşılması gerektiğini ortaya koymaktır.

\section{Tarımsal Arazinin Değerlemesi}

Taşınmazların değerlemesi ve bu değerlerin vergiye yansıtılması gelişmiş toplumların önemli ekonomik kaynaklarından birini oluşturmaktadır (Yomralıŏglu, Nişancı, Çete, \& Candaş, 2011). Tarımsal arazinin değerlemesi arazi üzerindeki ürünün, arazinin sahip olduğu gelir ve hakların değerinin belirlenmesi işlemidir. Değerleme yapılırken hangi yöntemin kullanılacağı bilgisinin yanında, değeri belirlenecek malın teknik ve ekonomik özellikleri de iyi bilinmelidir. Emsal alınacak arazilerin de nitelikleri araştırılıp değerlemeye etkileri göz önüne alınmalıdır. Değerleme için ihtiyaç duyulan veriler; arazi malikleriyle görüşülmesi, bölgedeki ilgili Gayrimenkul Değerleme Uzmanları, Tarım İl ve İlçe Müdürlüğü, Ziraat Odaları, Tapu Sicil Müdürlüğü, Belediye gibi kurum ve kuruluşlardan gerekli bilgilerin toplanması ile düzenlenmelidir.

Bir taşınmaza neden değer biçileceği önemlidir. Amacı bilinmeden bir taşınmaza değer biçilemez. Değerleme yapım amacı; kamulaştırma, arazi ipoteğine dayalı kredi, arazi ve tarımsal taşınmazların vergilendirilmesi, taşınmazlar üzerinde irtifak hakkı kurulması, zarar ve kayıp değerlerinin saptanması, tarımsal sigorta, alım-satım amacıyla tarım arazisinin kıymet takdiri, miras, çevre etki değerleme (Rehber, 2017) şeklinde sıralanabilir.

\subsection{Kıymet Takdirinde Yasal Süreç}

Ülkemizdeki kamulaştırmalarda, Kamulaştırma Kanunu gereği öncelikle satın alma yönteminin uygulanması; tarım arazilerinde gelir, arsalarda emsal değer ve yapılarda maliyet kriterlerine göre bedel hesaplanması yasal bir zorunluluktur. 
Kamulaştırma Kanununa (2942 sayılı) göre tarım arazilerinin kamulaştırma bedellerinin hesaplanmasında; “Taşınmaz mal veya kaynağın kamulaştırma tarihindeki mevki ve şartlarına göre ve olduğu gibi kullanılması halinde getireceği net gelirinin" dikkate alınması gerekmektedir. Kamulaştırma Kanunu'nda ifade edilen arazi net geliri, arazinin rantı olup kamulaştırma bedeli hesaplanırken bu değer dikkate alınmaktadır (Gazete, 1983).

Arazi değerlemesinde tarımsal üretim maliyeti, arazi piyasası ile ilgili veriler toplanmalı, bölgeyle ilgili özel kuruluşların verileri de dikkate alınmalı ve tüm veriler analiz edilmelidir. Arazi yetenek sınıflarına (Kuru Tarım, Sulu Tarım, Bağlık, Meyvelik, Kavaklık ) ve münavebelere göre arazilerin yıllık ortalama net gelirleri ve geçerli kapitalizasyon faiz oranları (KFO) belirlenmelidir. Arazinin gelir yöntemine göre değerini belirlemek için yıllık ortalama net gelir ve KFO bilinmelidir. Bunun için kullanılması gereken temel kapitalizasyon eşitliği (Mülayim, 2001);

\section{Arazi Değeri $(\mathrm{D})=$ Arazinin $\quad$ Yillık Ortalama Net Geliri $($ Rantı)(R)/}

Kapitalizasyon Faiz Oranı (f)
R: Net Gelir (Brüt Gelir - Giderler)
f: Kapitalizasyon Faiz Oranı
D: Bir dönüm alanın değeri

İşletme masrafları (giderler) brüt gelirin 1/3’ünden az olamaz (Dosya No:2018/946 Karar No:2018/902 - Dosya No:2018/945 Karar No:2018/901 - Dosya No:2018/954 Karar No:2018/903).

Tarımsal arazi değerlemesi hakkında ilişkilendirilen bilgiler;

- Bahçede üretim yapılıyor ise; Tarımsal üretim, Toprağın niteliği, Topografik durum, Arazideki ağaç adedi, yaşı, cinsi, üretim şekli, Sulama kaynakları, sulama sistemi, bahçenin ulaşım bilgileri

- Tarlada üretim yapılıyor ise; Tarla üzerindeki tarımsal ürün bilgisi, Sulu ve kuru üretim şekli, Sulu üretim yapılıyorsa suyun kaynağı hakkında bilgi, Tarlada birden fazla üretim yapılıyorsa her bir üretimin yapıldığı alan, Tarlanın ulaşım bilgileri, Tarla ile sınırı bulunan diğer tarlalardaki ürün bilgisi

-Serada üretim yapılıyor ise; Tarımsal ürün belirtilmeli (çay, findık, biber...), Üretim şekli (topraklı, topraksız), ilgili tarlanın ne kadarlık kısmında sera üretimi yapıldığı, seranın ısınma, su temin edilme şekli, sera boyutları ve cinsi, seranın ulaşım bilgileridir (ARVES, 2020).

Araziden elde edilen gelirin saptanmasında dikkat edilecek diğer bir husus münavebe düzenidir (Engindeniz, Başaran, \& Susam, 2015). Münavebe, aynı tarım alanı üzerinde farklı türden kültür bitkilerinin aralıklarla arka arkaya yetiştirilmesi işlemidir. Münavebenin doğru tanımlanması objektif 
bir değerleme için önemlidir. Münavebe bitkileri, arazinin iklim bölgesine, sulu ve kuru tarım arazisi olmasına ve fiziksel konumuna göre değişebilmektedir (Özel, 2015).

Tarım arazilerinde münavebenin yanında üretim masrafları da dikkate alınmalıdır. Maliyeti oluşturan masraflar; arazi kirası, işçilik masrafları, cari masraflar, amortismanlar ve faizdir (Rehber, 2017).

Arazinin kullanım veya verim değerine ulaşabilmek için, bu gelirlerin belirli bir faiz oranına göre kapitalize edilmesi gerekmektedir. Kapitalizasyon faizi, gelecekte elde edilmesi beklenen gelirlerin şimdiki zamana indirgeme oranıdır (Cennet \& Zühal, 2004).

KFO; sermaye kurtarma faktörü olup araziye yatırılmış sermayenin kullanma hakkıdır (Mülayim, 2001), karşılığı toprak olan sermayenin riskidir. Bu bağlamda araziye yatırılan sermayenin çok az riskli olması ve arazinin çok uzun yıllar kullanılabilmesi, taşınmazın ulaşım ve sosyal güvenilirliği, topoğrafik yapısı, merkezine yakınlığı, bölgede araziye olan talebin ve toprak sevgisinin çok fazla olması gibi hususlar ile belirlenmelidir. Çiftçinin arazisine bağlılı̆̆ isteği, arazisini gelecek için bir güvence olarak görmesi, arazisine işgücünü değerlendirecek bir yatırım olarak bakması gibi özellikler de dikkate alınmalıdır.

Para ve yatırım piyasasına başvurarak, açıklanan yaklaşımlarla bir KFO elde etmek, bu piyasalar hakkında risk, idarecilik masrafları, enflasyon, vergi uygulamaları gibi birçok açıdan bilgili olmayı gerektirmektedir.

Yargitay 18. Hukuk Dairesi (E.1990/5-507, K. 1990/539 ve T. 31.10.1990.) KFO için belirli özellikler dikkate alarak \%3 ile \%15 arasında bir yorum geliştirmiştir (Özel, 2015). KFO’nun \%3 alınabilmesi için taşınmazın; nüfus yoğunluğunun çok, arazinin kıt bulunduğu bölgeler seçilmelidir. $\mathrm{Bu}$ oranlar uygulanırken takdir komisyonlarının komisyon üyeleri iyi veri toplamalıdır. Araziyi gidip yerinde görmeli ve etki altında kalmamalıdır. Arazi değerinin artışına neden olacak başka bir kriter olması durumunda objektif değer artışı, komisyon üyelerince belirlenir. 2942 sayılı kamulaştırma kanununun 11. maddesine (Değişik: 19/4/2018-7139/27 md.) eklenen objektif değer artışının \% 50’yi geçmemesi yönündeki karar, Anayasa Mahkemesinin 10/4/2019 tarihli ve E.:2018/156; K.:2019/22 sayılı kararı ile iptal edilmiştir.

\subsection{Tarımsal Arazinin Vergilendirilmesi}

Vergi, Anayasada yer alan ve herkesin ödeme gücüne göre yerine getirmekle yükümlü olduğu bir görevdir (Can, Bülbül, \& Dağaşan, 2013). Tarım topraklarının vergilendirilmesi 193 sayılı Gelir Vergisi Kanunu (GVK) ve 1319 sayılı Emlak Vergisi Kanunu (EVK) gereğince yapılmaktadır.

Emlak vergisi için birim değer tespitine ilişkin komisyonlanı kurulur. Bu komisyonlara kıymet takdir komisyonları adı verilmektedir. Emlak vergisi dört yılda bir yapılan takdir işlemleri ile yeniden 
belirlenmektedir. Takdir komisyonları arsalar ve araziler için ayrı olarak oluşturulmaktadır. Ayrıca Büyükşehirlerde arsa ve araziye ait takdir komisyonu kararlarını inceleyecek merkez komisyon oluşturulmaktadır (Can et al., 2013).

Diğer taraftan Türkiye'de taşınmaz değer artışı geri kazanma mekanizması tam olarak kurulamamıştır. Bu nedenle taşınmaz değerindeki artıştan kaynaklı vergiye esas değer tam olarak belirlenememektedir. Ayrıca kamu yatırımları ile bölgede oluşabilecek değer artışları vergilendirilememektedir (Baser, Uzun, \& Yildirim, 2019; Başer, 2019). Bu bağlamda taşınmaz değerindeki artış mülk sahibi ile kamu arasında paylaşılmalıdır. Ekonomik istikrar, sosyal barış ve huzurun sağlanması ancak çıkarların dengelenmesi ile oluşabilecektir. Gelişmekte olan ülkelerde rant paylaşımı kamu lehine fazla olmalıdır. Çünkü altyapı yetersizliklerini gidermek ve kaliteli bir yaşam çerçevesi oluşturmak üretici olmayan sermaye gücüne bağımlıdır.

\section{Materyal ve Yöntem}

$\mathrm{Bu}$ araştırma da taşınmaz değerlemesine konu tarım arazilerinin değerlendirilmesinde hangi hususlara dikkat edilmesi gerektiği ve diğer taşınmazların değerlemesinde kullanılan yöntemlerden nerelerde ayrıldığını, değerlemede oluşan mevcut sorunlara nasıl çözümlerle yaklaşılması gerektiğini ortaya koymak amaçlanmaktadır. Bu bağlamda çalışma kapsamında mülakat metodu kullanılarak alanında uzman 12 kişi ile görüşülüp önceden hazırlanan sorular kendilerine yöneltilmiş ve 5 mülakat değerlendirmeye alınmıştır. Bu 5 mülakat, sorulara yeterli açıklayıcı bilgiyi veren, verdiği bilgi diğer örneklem grubu üyelerine kıyasla daha tatmin edici düzeyde olan mülakatlar seçilmiştir. Mülakat soruları yöneltilen kişilere, isimleri belirtilmeden örneklem grubu adı altında her biri için bir kod verilmiştir. Mülakata katılanların kişisel bilgilerine ilişkin veriler Tablo 1'de gösterilmiştir. Ayrıca konuya ilişkin bilirkişi rapor örnekleri analiz edilmiş ve sunulmuştur.

Tablo 1. Örneklem Grubu Kişisel Bilgileri.

\begin{tabular}{|l|l|l|l|l|l|}
\hline & A & B & C & D & E \\
\hline Cinsiyet & Erkek & Erkek & Erkek & Erkek & Erkek \\
\hline $\begin{array}{l}\text { Çalıştığ } \\
\text { Kurumlar }\end{array}$ & $\begin{array}{l}\text { Özel } \\
\text { Sektör }\end{array}$ & $\begin{array}{l}\text { Özel } \\
\text { Sektör, } \\
\text { Kamu }\end{array}$ & $\begin{array}{l}\text { Özel Sektör, } \\
\text { Gayrimenkul } \\
\text { Değerleme } \\
\text { Uzmanı }\end{array}$ & $\begin{array}{l}\text { Özel Sektör, } \\
\text { Gayrimenkul } \\
\text { Değerleme } \\
\text { Uzmanı }\end{array}$ & $\begin{array}{l}\text { Özel Sektör, } \\
\text { Belediye }\end{array}$ \\
\hline Unvan & Avukat & $\begin{array}{l}\text { Ziraat } \\
\text { Müh. }\end{array}$ & Harita Müh. & Ziraat Müh. & $\begin{array}{l}\text { Harita Yük. } \\
\text { Müh. }\end{array}$ \\
\hline $\begin{array}{l}\text { Eğitim } \\
\text { Durumu }\end{array}$ & L & L & L, & L & L, YL \\
\hline $\begin{array}{l}\text { Değerleme } \\
\text { Tecrübesi }\end{array}$ & U, K & U, K & U, BK & U & U, K \\
\hline
\end{tabular}

BK: Bilir Kişi, K: Kontrol, L: Lisans, U:Uygulama, YL: Yüksek Lisans 


\section{Bulgular}

$\mathrm{Bu}$ bölümde, önceden hazırlanan yarı yapılandırılmış mülakat sorularına, örneklem grubunun verdiği cevaplar başlıklarına göre gruplandırılmıştır. Son kısımda ise bilirkişi rapor örneklerinden analizler yapılarak sunulmuştur.

Taşınmaz değerlemesinde arsa ve arazi farklılıklarına ulaşmak adına;

Bir taşınmazın değerlemesinde, arsa ve arazi ayrımını nasıl yapıyorsunuz? Taşınmazın arsa veya arazi olması, malikin ödeyeceği emlak vergisini nasıl değiştirir? Arazinin emlak vergisi nasıl, hangi periyotlarda, kimler tarafindan belirlenir? Kentsel alanda, arazi olarak kullanılan, hukuki yönden arsa vasfındaki bir taşınmazın değerlemesi, kamulaştırma ve tapu iptali-tescil davalarında, ayrı ayrı, nasıl yapılmalıdır? Kentsel alanda, arsa olarak kullanılan, hukuki yönden arazi vasfındaki bir taşınmazın değerlemesi, kamulaştırma ve tapu iptali-tescil davalarında, ayrı ayrı, nasıl yapılmalıdır? Kırsal alanda, arazi olarak kullanılan, hukuki yönden arsa vasfındaki bir taşınmazın değerlemesi, kamulaştırma ve tapu iptali-tescil davalarında, ayrı ayrı, nasıl yapılmalıdır? Kırsal alanda, arsa olarak kullanılan, hukuki yönden arazi vasfındaki bir taşınmazın değerlemesi, kamulaştırma ve tapu iptali-tescil davalarında, ayrı ayrı, nasıl yapılmalıdır? Sorularının sorulması sonucu alınan cevaplar Tablo 2'de yer almaktadır.

Tablo 2: Taşınmaz Değerlemesinde Arsa ve Arazi Farklı1ı̆̆ Başlığı Altındaki Cevaplar

\begin{tabular}{|c|l|}
\hline A & $\begin{array}{l}\text { İmar planı içerisinde ise ve belediyenin bütün hizmetlerinden faydalanıyorsa arsa, } \\
\text { değilse arazidir. Arsa vergisi araziden fazladır. } 4 \text { yılda bir komisyonlar tarafından } \\
\text { belirlenir. Kentsel alanda arazi olarak kullanılsa da arsa üzerinden değer belirlenir, ürün } \\
\text { eklenir. Demek ki taşınmaz kadastral parsel, bu durumda arsa olarak değerleriz ama } \\
\text { imar parseli kadar değerli değildir. Cins değişikliği ile arsa olarak yazdırmış olabilir } \\
\text { ama önemli olan imar planı durumudur. Planlı alanda değilse arazi olarak değerlenir. } \\
\text { Belediye özel bir plan yapmış olabilir. Arsa olarak değerlenebilir. }\end{array}$ \\
\hline B & $\begin{array}{l}\text { İmar planı içerisinde ise ve belediyenin bütün hizmetlerinden faydalanıyorsa arsa, } \\
\text { değilse arazidir. Arazinin rayiç bedelinin 10.000 TL'yi aşması durumunda emlak } \\
\text { vergisi alınır. 4 yılda bir komisyonlar tarafından belirlenir. Gelecekte arsa ama şuan } \\
\text { mevcut durumda arazi olması ne tam arazi olarak nede arsa olarak değerleyemiyoruz } \\
\text { Arsa için gerekli koşulları sağlaması halinde arsa olarak değerlendirilir. Taşınmaz arsa } \\
\text { vasfinda olsa bile uygulamada gözlemlerimiz sonucu kullanımının arazi olması o } \\
\text { taşınmazın değerinin arazi üzerinden yapılacağı anlamına gelir. Kırsal alanda arsa } \\
\text { olarak kullanılması taşınmazın değerinin arsa üzerinden yapılacağını gösterir. }\end{array}$ \\
\hline
\end{tabular}




\begin{tabular}{|c|c|}
\hline $\mathrm{C}$ & $\begin{array}{l}\text { İmar planı ve meskûn alanda ise arsa değilse arazidir. Arsa vergisi araziden fazladır. } 4 \\
\text { yılda bir komisyonlar tarafından belirlenir. Belediyeden gelen yazı ile ilgili taşınmazın } \\
\text { hukuki yönü arsa ise bu taşınmaza arsa olarak değerleme yaparız. Bu durumda diyelim } \\
\text { ki tapuda tarla arazisi fakat mücavir alan içerisinde oluşu, imar planı içerisinde oluşu } \\
\text { ve tüm belediye hizmetlerinden faydalanması taşınmazı arsa olarak değerlendirmemizi } \\
\text { sağlıyor. Bu taşınmazın değerlemesi de eğer ki arsa vasfını taşıyacak nitelikte fakat } \\
\text { arazi olarak kullanılıyorsa o zaman arsa olarak değerleme yaparız. Bu taşınmaz arsa } \\
\text { vasıflı bir taşınmazın değerlemesi gibi değerleme yapılır. Bu araziye arsa vasfındaki } \\
\text { taşınmazın özelliklerini taşıyorsa objektif değer artışına götürülür. }\end{array}$ \\
\hline $\mathrm{D}$ & $\begin{array}{l}\text { Tüm belediye hizmetlerinden yararlanıyorsa, mücavir alan içerisinde ise, meskûn } \\
\text { mahal ise imar planı içinde veya dışında olmasına bakılmaksızın arsa kabul edilir. Arsa } \\
\text { vergisi araziden fazladır. } 4 \text { yılda bir komisyonlar tarafından belirlenir. Taşınmazın } \\
\text { değerini kullanım biçiminden belirleriz, ancak vasfının arsa olması nedeniyle değerini } \\
\text { arttırıcı yönde bir değerleme yaparız. Taşınmazın vasfı arazide olsa arsa olarak } \\
\text { kullanılması bizim için önceliklidir. Bu nedenle her iki davada da arsa üzerinden değer } \\
\text { belirlenir. Kırsal alanda vasfının arsa olması taşınmazı arsa yapmaz. Eğer bir taşınmaz } \\
\text { imar planı içerisinde değilse arazi olarak belirlenir ve değer bu vasıf üzerinden } \\
\text { hesaplanır. Böyle bir uygulamayla karşılaşmamakla birlikte kırsal alanda arsa vasfının } \\
\text { olması özel bir durum olabilir. }\end{array}$ \\
\hline $\mathrm{E}$ & $\begin{array}{l}\text { İmar planı, mücavir alan içinde ise ve belediye hizmetlerinden yararlanıyorsa arsa, } \\
\text { değilse arazidir. Alım tarihinden } 5 \text { yıl içerisinde satış oluyorsa gelir vergisinin yanında } \\
\text { emlak vergisi de alınır. Komisyonlar tarafından belirlenir. İmar planı içerisinde ise ve } \\
\text { tapu da arsa olarak kayıtlı ise bu alan artık arsa olarak nitelendirilir. Kentsel alandaki } \\
\text { taşınmaz zaten imar geçmişse o taşınmaz arsa vasfında nitelendirilir. 18.madde } \\
\text { uygulaması yapılmışsa imar parseli, yapılmamışsa kadastro parselidir. Buna göre } \\
\text { değerlendirme yapılır. Tapu Niteliği arsa ise değiştirmeyiz direkt arsa olarak alırız } \\
\text { Kırsalda tapusu arazi olup ama arsa olarak kullanılan bir taşınmaza rastlanmamıştır. }\end{array}$ \\
\hline
\end{tabular}

Arazi Dĕgerlemesinin nasıl yapıldı̆̆ına ulaşmak adına;

Arazi değerlemesinde kullanılan, kapitalizasyon faiz oranı nedir? Nasıl ve neye göre belirlenir? $\mathrm{Bu}$ oran dışında değere etki edecek farklı oran veya katsayılar da var mıdır? Arazi üzerindeki mahsulün çeşitliliği, farklı kullanım alanları (tarla, fındık bahçesi, arsa, bina, ahır vb.) değerlemeyi nasıl etkiler? Bu tip karma kullanıma sahip taşınmazlarda değerleme yaparken hangi unsurlar göz önüne alınmalıdır? Objektif değer artışı kavramı nedir? Tarım arazilerinde bu değer nasıl belirlenir? Uygulamada bu değere ilişkin maksimum veya minimum bir takım kısıtlamalar var mıdır? Arsa ve arazi vasfındaki taşınmazların değerlemesinde, zemin üzerinde muhdesat şeklinde bulunan ağaçların değerlemeye etkisi olur mu? Bu etki ağacın türü, yaşı, büyüklüğü ve cinsi gibi faktörlere göre nasıl hesaplanır? Arazi vasfında olup da, üzerinde herhangi bir yapı veya ürün bulunmayan taşınmazın değerlemesi nasıl yapılır? Sorularının sorulması sonucu alınan cevaplar Tablo 3'de yer almaktadır. 
Tablo 3: Arazi Değerlemesinin Nasıl Yapıldığı Başlığı Altındaki Cevaplar

\begin{tabular}{|c|c|}
\hline A & $\begin{array}{l}\text { Sermaye kurtarma faktörü olup, araziye yatırılmış sermayenin kullanma hakkıdır.\%33 } \\
\text { ile \%15 arasında değişir. Ağaçların cinsi, yaşı ve verim durumu dikkate alınarak } \\
\text { maktuen değer biçilir. Bu değerler arazi değerine eklenir. Yerin değeri belirlendikten } \\
\text { sonra değerin daha fazla edebileceğini düşündügümüzde bazı değer artıcı unsurları } \\
\text { belirterek değer artışı uygulanmasıdır. Belirlediğimiz taşınmaz değerinin üzerine ağaç } \\
\text { bedelini de ekliyoruz. Ama eğer kapama değil de münferitse o zaman ağacın yaş ve } \\
\text { cinsine göre maktuen bedelini buluyoruz. Boş arazideki değer belirlenirken arazinin } \\
\text { konumuna, bakısına, hâkim bitki örtüsüne bakıyoruz. }\end{array}$ \\
\hline B & $\begin{array}{l}\text { Kapitalizasyon faiz oranı arazinin gerçek değerinin satış değerine oranıdır. Tarım } \\
\text { arazilerinin hesaplanmasında kullanılır. Bu değer Yargıtay'da \%3 ile \%15 arasındadır. } \\
\text { Ürünlerin kilo, satış, masrafına göre getirisini öğreniriz. Ürünlerin ayrı ayrı değerler } \\
\text { hesaplanıp taşınmazın değeri üzerine eklenir. Objektif değer artışı kapitalizasyon faiz } \\
\text { oranının taşımadığı özellikleri taşır. Çeşitlerine göre gruplandırılarak Gıda Tarım ve } \\
\text { Hayvancılık İl Müdürlükleri tarafından belirlenen değerler doğrultusunda değerlemesi } \\
\text { yapılır. 18. maddede sayılan yöntemler içinde, boş arsa ve arazilerin değerlemesinde } \\
\text { kullanılabilecek iki yöntem Ekspertiz Değeri ve Tasfiye Değeri metotlarıdır. }\end{array}$ \\
\hline C & $\begin{array}{l}\text { Arazinin tek bir parçadan oluşması gibi faktörler kapitalizasyon oranını belirlemede } \\
\text { etkili olur. Bu oran dışında değere etki eden oran objektif değer artış oranıdır. Arazideki } \\
\text { mahsul çeşitliliğine göre tek tek her çeşide göre değer verilir. Objektif değer artışı } \\
\text { arazilerde kullanılır. Kapitalizasyon faiz oranının kapsadığı özellikler dışında } \\
\text { değerlemeyi etkileyecek başka faktörlerinde bulunması durumunda objektif değer } \\
\text { artışına gidilir. Bu etki ağacın cinsi, yaşı, büyüklüğ̈üne bakılarak araziler üzerinde } \\
\text { maktuen değer biçilir. Tek tek ağaçlara değer verilir. Eğer ki üzerinde herhangi bir yapı } \\
\text { ve ürün bulunmayan yani boş arazinin değerlemesi için etrafındaki emsal alınabilecek } \\
\text { arazilere bakılarak değerlemesi yapılır. }\end{array}$ \\
\hline D & $\begin{array}{l}\text { Kapitalizasyon faiz oranı, araziden elde edilmesi beklenen getiri oranıdır. Arazi } \\
\text { üzerindeki karma ürünler için genellikle ürünlerin getirisini ilgili kurumlardan } \\
\text { öğrendikten sonra ortalama bir getiri belirlenir. Objektif değer artışı sadece araziler için } \\
\text { geçerli olan bir kavramdır. Öncelikle taşınmazın cinsini belirleriz ve cinsi üzerinden bir } \\
\text { değer hesapları. Boş arsa ve arazilerin değerlenmesinde kullanılacak iki yöntem } \\
\text { Ekspertiz Değeri ve Tasfiye Değeri kullanılır. }\end{array}$ \\
\hline $\mathrm{E}$ & $\begin{array}{l}\text { Kapitalizasyon faiz oranı, araziye yatırılmış birim sermayenin kullanılma hakkıdır. } \\
\text { Tarım arazilerinin hesaplanmasında kullanılır. Bu değer \%3 ile \%15 arasındadır. } \\
\text { Kıymet takdir komisyonu fiyat belirler. Arazi üzerindeki mahsulün çeşitliliği, farklı } \\
\text { kullanım alanları değerlemeyi etkileyen unsurlardır. Mahsullerin çeşidine göre } \\
\text { değerleme yapılır. Kapitalizasyon faiz oranının taşımayan özellikleri ile objektif değer } \\
\text { artışına gidilir. }\end{array}$ \\
\hline
\end{tabular}

\section{Bilirkişi rapor örneklerinin analizi;}

Mahkemelere yapılan başvurularda itirazlara konu olan taşınmazlara ilişkin teknik bilirkişi raporlarında;

1. Taşınmazın Cinsi ve Özellikleri; Bu bağlamda taşınmaza ilişkin bilgiler toplanmaktadır. Taşınmazın yüzölçümü, eğimi, arazinin toprak yapısı, vasfı, üzerinde yapı bulunun bulunmadığı, hâkim bitki örtüsü ve bölgenin coğrafi yapısı gibi veriler toplanmaktadır. 
2. Taşınmaz Üzerindeki Ürün Miktarları ile $\mathbf{m}^{2}$ Değerleri; Gayri Safi Gelir tespitinde yıllık dekardaki ürün miktarları, parselin mevcut durumu, toprağın yapısı ve tarımsal faktörler dikkate alınmaktadır. Üretim masraflarının hesaplanmasında budama, gübre ve gübreleme, ilaç ve ilaçlama, işçilik, hasat, nakliye vb. masraflar dikkate alınmaktadır. Ürün fiyatlarının tespitinde Gıda, Tarım ve Hayvancılık Bakanlığı İl Müdürlügüünün istatistiklerinden yararlanılmıştır.

3. Kapitalizasyon Faiz Oranının Tespiti; “Yargltay uygulaması ile benimsenen bilimsel verilere göre, Türkiye genelinde kapitalizasyon faiz oranı 3 ile 15 arasında değişmektedir. Kapitalizasyon faiz oranının \% 3 alınabilmesi için taşınmazın; nüfus yoğunluğunun çok, arazinin kut bulunduğu Karadeniz Sahil Bandı gibi bölgelerde bulunması gerekmektedir.” (Yargitay 5. Hukuk Dairesi -2009/18740 Esas -2010/5280 karar)

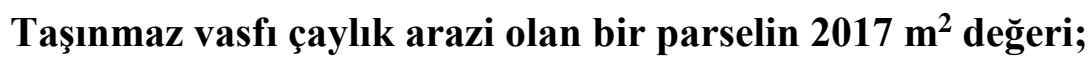

1 dekar Çaylığın Gayri Safi Geliri;

$\begin{array}{ll}\text { Gayri Safi Gelir } & =\text { Dekara ortalama verim } x \text { ürün fiyatı } \\ \text { Yaş Çay } & =1.000 \mathrm{~kg} / \mathrm{da} \times 1,0 \mathrm{TL} \\ & =1.900,00 \mathrm{TL} \\ & =850,00 \mathrm{TL} \\ & =\text { Gayri Safi Gelir }- \text { Üretim Masrafları } \\ & =1.900,00 \mathrm{TL}-850,00 \mathrm{TL} \\ \text { Üretim Masrafları } & =1.050,00 \mathrm{TL} \\ \text { Net Gelir } & =\text { Net Gelir/ Kapitalizasyon Faizi } \\ & =1.050,00 \mathrm{TL} / 0,03=35000 \mathrm{TL} \\ 1 \text { dekar Çaylı̆̆ın değeri } & =35000 \mathrm{TL} / \mathbf{1 0 0 0} \\ \mathbf{1} \mathbf{~ m}^{\mathbf{2}} \text { çaylık arazinin değeri } & =\mathbf{3 5 , 0 0} \mathbf{T L} / \mathbf{m}^{\mathbf{2}} \mathbf{d i r} .\end{array}$

\section{Sonuç ve Öneriler}

Ülkemizde taşınmaz değerleme konusunda mevzuat ve yönetim açısından aksaklıklar olduğu ortadadır. Taşınmaz değerlemenin bir parçası olan tarım arazilerinin değerlemesinde daha ciddi yasal düzenlemelerin yapılması gerekmektedir. Bu amaçla; yarı yapılandırılmış mülakat sorularından elde edilen veriler ve uygulamada karşılaşılan sorunlar karşılaştırılmıştır.

Tarım arazilerinin değerlemesinde bazı gereksinimler belirlenmiş ve aşağıda sunulmuştur.

- Tarım arazilerinin bazıları hâlihazırda arsa olarak kullanılabilmektedir. Bu tip arazilerin değerlemesi arsa nitelikli taşınmazların değerlemesi şeklinde yapılmaktadır. Eğer üzerinde zirai ürünler veya muhdesat mevcut ise bunlar zemin değeri üzerine eklenerek taşınmazın 
değeri hesaplanmaktadır. Tersi durumda ise, yani taşınmaz arsa olarak kullanılıyor ancak arazi vasfında ise, bu tip taşınmazlar da arsa olarak belirlenmektedir.

- Tarım arazilerinde rayiç bedelinin 10,000 TL'yi aşması durumunda emlak vergisi alındığı, KFO’nun uygulamada \%3-\%15 arasında belirlendiği, KFO’nun taşımadığg özellikleri objektif değer artışı kavramı ile bertaraf edildiği belirlenmiştir.

- Değerlemenin çok ayrıntılı, teknik, hukuki ve ekonomi bilgisi gerektiren bir uzmanlık alanı olduğu unutulmadan, taşınmaz değerini gerçekleştiren özel şirketlerin varlığının kuvvetlendirilmesi gerekmektedir.

- Bilirkişilik kurumunun oluşturularak aktif hale getirilmesi gerekmektedir. Alanında uzman kişilerin bilirkişiliklerde görev alması sağlanmalıdır.

- Boş duran arsaları vergilendirme, imar hakkının harca bağlanması, kentsel toprakların fiyatlarının dondurulması, değer tespiti ve arazi fiyatları ile doğrudan ilişkilidir.

- Alım - satım işlemleri sırasında alınan tapu harcı vatandaşın beyanı üzerinden gerçekleştirilmekte, bu da alınacak verginin çok az olmasına neden olmaktadır.

- Değer haritalarının oluşturulamaması nedeni ile arsa pazarında devletin etkisi azalmakta ve haksız kazanç oluşmaktadır.

- Kamusal yatırımlar sonucu (yol, okul, park vb.) ortaya çıkan değer artışından devlet ekonomik olarak yararlanamamaktadır (Örneğin kamulaştırma sonucunda bazı parsellerde oluşan değer artışından şerefiye payının kaldırılmasından dolayı devletin yararlanamaması gibi).

- Güvenilir bir değerlendirme için vergiye konu nesneler, kadastral parseller, yüzey alanı ve parsellerin özellikleri bilinmelidir. Tapu daireleri, vergi daireleri arasında uygun ara yüzler oluşturularak bilgi akışı sağlanmalıdır.

\section{Kaynaklar}

ARVES. (2020). Tarım Değerleme. Retrieved from https://www.arvesgd.com.tr/tarim-degerleme.html

Baser, V., Uzun, B., \& Yildirim, V. (2019). An alternative method for expropriation for lane-like projects in planned area: a case study from Trabzon in Turkey. Survey Review, 51(365), 147-153.

Başer, V. (2019). Kamu Ulaşım Yatırımlarının Taşınmaz Üzerindeki Etkileri: Ordu-Giresun Havalimanı Örneği. Karadeniz Fen Bilimleri Dergisi, 9(1), 82-93.

Başer, V., Biyik, C., Uzun, B., Yildirim, V., \& Nişancı, R. (2016). A Recommendation of decision-support model based on geographical information systems for generating real estate evaluation maps: kaşüstü/trabzon example. Sigma: Journal of Engineering \& Natural Sciences/Mühendislik ve Fen Bilimleri Dergisi, 34(3).

Can, B., Bülbül, Z., \& Dağaşan, V. (2013). Açıklamalı ve İçtihatlı Belediyelerde Emlak Vergisi Uygulaması. Türkiye Belediyeler Birliği, Ankara, Ocak.

Cennet, O., \& Zühal, Ü. (2004). Konya ili çumra ilçesi sulu tarim arazilerinde kapitalizasyon faiz oraninin tespiti. Selcuk Journal of Agriculture and Food Sciences, 18(33), 8-16.

Choumert, J., \& Phélinas, P. (2015). Determinants of agricultural land values in Argentina. Ecological Economics, 110, 134-140.

Enemark, S. (2012). Sustainable land governance. FIG Working Week, Rome, Italy, 6-10. 
Engindeniz, S., Başaran, C., \& Susam, B. (2015). Tarım arazilerinin kamulaştırma bedellerinin saptanmasında gelir yönteminin uygulanmasıyla ilgili anlaşmazlıklar. TMMOB Harita ve Kadastro Mühendisleri Odast, 15.

Gazete, R. (1983). 2942 Sayılı Kamulaştırma Kanunu. T, 8(1983), 18215.

Gazete, T. C. R. (2018). Bakanlıklara Bağl1, İlgili, İlişkili Kurum ve Kuruluşlar ile Diğer Kurum ve Kuruluşların Teşkilatı Hakkında 4 Nolu Cumhurbaşkanlığı Kararnamesi. Erişim adresi: http://www. resmigazete. gov. tr/eskiler/2018/07/20180715-1. pdf Erişim tarihi, 15, 2019.

Mülayim, Z. (2001). Tarımsal Değer Biçme ve Bilirkişilik, Yenilenmiş ve Genişletilmiş 2. Baskr, Yetkin Yayınlarl, Ankara.

Özalp, A. Y., Akıncı, H., \& Kılıçer, S. T. (2020). Artvin Örneğinde Arsa Vasıflı Taşınmaz Malların Değerini Etkileyen Faktörlerin Analizi. Geomatik, 5(2), 100-111.

Özel, S. (2015). Tarımsal Arazilerin Kamulaştırma Bedelinin Tespitine Yönelik Yasal Ölçütlerin Mülkiyet Hakkı Açısından İncelenmesi. Batman Üniversitesi Yaşam Bilimleri Dergisi, 5(1), 162-181.

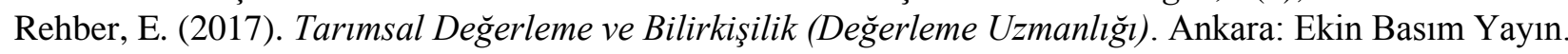

TUIK. (2020). Tarım Alanları. Retrieved from https://data.tuik.gov.tr

Yalçın, G., Selçuk, O., \& Şentürk, E. (2018). Bursa İli Mustafakemalpaşa İlçesi Tarım Arazilerinde Kapitalizasyon Oranının Tespiti. Afyon Kocatepe Üniversitesi Fen Ve Mühendislik Bilimleri Dergisi, 18(2), 548-560.

Yomralığlu, T., Nişancı, R., Çete, M., \& Candaş, E. (2011). Dünya'da ve Türkiye'de Taşınmaz Değerlemesi. 